\title{
Human Norovirus Replication in Temperature-Optimized MDCK Cells by Forkhead Box 01 Inhibition
}

\author{
Eun-Hye Jeong ${ }^{1 \dagger}$, Se-Young Cho ${ }^{1 \dagger}$, Bipin Vaidya ${ }^{1 \dagger}$, Sang Hoon $\mathrm{Ha}^{2}$, Sangmi Jun ${ }^{3,5}$, Hyun-Joo Ro ${ }^{3,5}$, \\ Yujeong Lee, ${ }^{4,5}$ Juhye Lee ${ }^{1}$, Joseph Kwon ${ }^{3 *}$, and Duwoon Kim ${ }^{1 *}$ \\ 'Department of Food Science and Technology and Foodborne Virus Research Center, Chonnam National \\ University, Gwangju 61186, Republic of Korea \\ ${ }^{2}$ Division of Biotechnology, Chonbuk National University, Iksan 54596, Republic of Korea \\ ${ }^{3}$ Biological Disaster Analysis Group, Korea Basic Science Institute, Daejeon 34133, Republic of Korea \\ ${ }^{4}$ Korea Basic Science Institute, Cheongju 28119, Republic of Korea \\ ${ }^{5}$ Convergent Research Center for Emerging Virus Infection, Korea Research Institute of Chemical Technology, \\ Daejeon 34114, Republic of Korea
}

\begin{abstract}
Human noroviruses (HuNoVs) are a leading cause of gastroenteritis outbreaks worldwide. However, the paucity of appropriate cell culture models for HuNoV replication has prevented developing effective anti-HuNoV therapies. In this study, first, the replication of the virus at various temperatures in different cells was compared, which showed that lowering the culture temperature from $37^{\circ} \mathrm{C}$ significantly increased virus replication in Madin-Darby canine kidney (MDCK) cells. Second, the expression levels of autophagy-, immune-, and apoptosis-related genes at $30^{\circ} \mathrm{C}$ and $37^{\circ} \mathrm{C}$ were compared to explore factors affecting HuNoV replication. HuNoV cultured at $37^{\circ} \mathrm{C}$ showed significantly increased autophagy-related genes (ATG5 and ATG7) and immune-related genes (IFNA, IFNB, ISG15, and NFKB) compared to mock. However, the virus cultured at $30^{\circ} \mathrm{C}$ showed significantly decreased expression of autophagy-related genes (ATG5 and ATG7), but not significantly different major immune-related genes (IFNA, ISG15, and NFKB) compared to mock. Importantly, expression of the transcription factor FOXO1, which controls autophagy- and immune-related gene expression, was significantly lower at $30^{\circ} \mathrm{C}$. Moreover, FOXO1 inhibition in temperature-optimized MDCK cells enhanced HuNoV replication, highlighting FOXO1 inhibition as an approach for successful virus replication. In the temperature-optimized cells, various HuNoV genotypes were successfully replicated, with GI.8 showing the highest replication levels followed by GII.1, GII.3, and GII.4. Furthermore, ultrastructural analysis of the infected cells revealed functional HuNoV replication at low temperature, with increased cellular apoptosis and decreased autophagic vacuoles. In conclusion, temperature-optimized MDCK cells can be used as a convenient culture model for HuNoV replication by inhibiting FOXO1 and providing adaptability to different genotypes.
\end{abstract}

Keywords: Autophagy, forkhead box 01, human norovirus, virus replication

\section{Introduction}

Norovirus, a non-enveloped single-stranded positive-sense RNA virus belonging to the Caliciviridae family, is classified into seven genogroups (GI-GVII) based on the capsid viral protein (VP)1 sequence [1]. Among them, GI, GII, and GIV cause acute gastroenteritis to humans, and therefore, are collectively referred to as human norovirus (HuNoV), which accounts for more than $95 \%$ of all viral gastroenteritis outbreaks worldwide [2,3]. GI only infects humans; however, GII can infect porcupines and swine, and GIV infects felines and canines as well as humans, thus GII and GIV are considered to have zoonotic potential [1].

The study of $\mathrm{HuNoV}$ transmission and the development of effective antiviral interventions are mainly hindered by a lack of an appropriate in vitro culture system. Many cell lines derived from humans and animals cannot support $\mathrm{HuNoV}$ replication [4,5]; for example, viral replication failed in three-dimensional models using human intestinal cells (Int-407 and Caco-2) [6, 7]. However, HuNoV genotypes GI.1, GII.4 and GII.17 were found to replicate in stem cell-derived human intestinal enteroids (HIE) [8], and a strain of GII.4 was reported to replicate in human B cells with enhanced replication by co-incubation with histo-blood group antigen (HBGA)-expressing bacteria $[9,10]$. Depending on the genotypes, HuNoV interacts with specific attachment factors such as HBGA or sialoglycan $[9,11]$. Although the presence of attachment factor facilitates interaction with the cell surface, the cells 
may not be susceptible to virus replication. Furthermore, Madin-Darby canine kidney (MDCK) cells were reported to have the well-polarized experimental epithelial cell system for the study of virus infection, and be susceptible to many pathogenic viruses, including canine adenovirus, influenza A, and influenza B virus [12-15]. In addition, even though GIV.2 and GVI are classified as canine norovirus, GI and GII were also reported to be found in the feces of a canine species, such as dog [16], indicating that HuNoV can enter into canine cell lines.

Temperature affects viral replication in host cells by modulating either the rate of synthesis of viral proteins and genomes or the host cell immune response [17-19]. Temperature sensitivity of the viral polymerase activity is usually reported to be responsible for modulating both transcription and replication of virus genome [18]. Apart from this, temperature also regulates host immune response against the virus, which consequently affects viral replication [20]. Furthermore, the transcription factor forkhead box O1 (FOXO1) also plays a key role in regulating immune response, and is further associated with the replication of different viruses, including hepatitis $\mathrm{B}$, vesicular stomatitis, and Newcastle disease viruses [21, 22]. However, the effect of temperature and FOXO1 expression in $\mathrm{HuNoV}$ replication has not been reported yet.

Hence, the present study was designed to investigate whether temperature optimization would facilitate HuNoV replication in MDCK cells. Our study demonstrated that MDCK cells can be used as an in vitro model to cultivate $\mathrm{HuNoV}$ by modulating temperature via FOXO1 signaling.

\section{Materials and Methods \\ Cell Lines and Reagents}

MDCK cells were purchased from the Korean Cell Line Bank (Korea; KCBL10034). The cells were cultured in Dulbecco's modified Eagle's medium (DMEM, Welgene) containing 10\% fetal bovine serum (Gibco) and 1\% penicillin-streptomycin (100 U/ml; Sigma-Aldrich, USA) at $37^{\circ} \mathrm{C}$ and $5 \% \mathrm{CO}_{2}$. For viral infection, the cells were cultured in DMEM supplemented with $100 \mu \mathrm{g} / \mathrm{ml}$ streptomycin, $100 \mathrm{U} / \mathrm{ml}$ penicillin, and trypsin treated with $2 \mu \mathrm{g} / \mathrm{ml} \mathrm{N}$-tosyl-L-phenylalanine chloromethyl ketone (TPCK; Sigma-Aldrich). Stock solutions of AS1842856 (Calbiochem, USA) were prepared in dimethyl sulfoxide (Sigma-Aldrich) and stored at $-20^{\circ} \mathrm{C}$.

\section{Ethics Statement}

Four HuNoV genotypes (GI.8, GII.1, GII.3, and GII.4), isolated separately from HuNoV-positive fecal samples, were obtained from the Gwangju Institute of Health and Environment. All patient information related to the specimens was anonymized for research purposes. The experimental protocol adopted in this study was approved by the Bioethics Review Committee of Chonnam National University (IRB No. 1040198-170420-HR-038-05).

\section{Virus Stock and Infection}

HuNoV specimens isolated from fecal samples were diluted to $10 \%$ in $\mathrm{PBS}(\mathrm{pH} 7.4)$ and stored at $-80^{\circ} \mathrm{C}$ until use. For the infection of MDCK cells, the HuNoV specimens were diluted in infection media consisting of DMEM containing $1 \%$ penicillin/streptomycin and $2 \mu \mathrm{g} / \mathrm{ml} \mathrm{TPCK}$. All experiments, excluding a test for adoptability of the culture system to cultivate different HuNoV genotypes, were performed with GII.4 genotype of HuNoV in 48 -well plates. The cells were cultured in a 48 -well plate at $6.25 \times 10^{4}$ cells $/ \mathrm{ml}$ at $37^{\circ} \mathrm{C}$ for $24 \mathrm{~h}$. The cells were infected with $1.91 \times 10^{2}$ genome copies of HuNoV GII.4 for one $h$, and the cells were then washed with PBS to remove unbound virus. After complete removal, the infected cells were incubated for $72 \mathrm{~h}$ at $27^{\circ} \mathrm{C}, 30^{\circ} \mathrm{C}, 34^{\circ} \mathrm{C}$, and $37^{\circ} \mathrm{C}$ in an atmosphere of $5 \% \mathrm{CO}_{2}$. The infected cells were scraped to extract RNA for virus quantification. To observe the passage of the virus, MDCK cells were cultured in concentrations of $6.25 \times 10^{4} \mathrm{cell} / \mathrm{s} / \mathrm{ml}$ in $0.75-\mathrm{cm}^{2}$ dishes (48-well plate), $1.375 \times 10^{5}$ cells $/ \mathrm{ml}$ in $21.50-\mathrm{cm}^{2}$ dishes $\left(60-\mathrm{mm}\right.$ culture dish) and $5.156 \times 10^{5} \mathrm{cells} / \mathrm{ml}$ in $75-\mathrm{cm}^{2}$ dishes (75T-Flask) for three consecutive passages. The cells were infected with HuNoV by incubation for $72 \mathrm{~h}$ in the $1^{\text {st }}$ and $2^{\text {nd }}$ passages and for two weeks in the $3^{\text {rd }}$ passage. For every subsequent passaging, the whole supernatant from the previous passage was used as an inoculum source. To test the adaptability of the culture system for the replication of different genotypes, the cells were infected with $2.28 \times 10^{2}$ virus genome copies of four different genotypes of HuNoV, including GI.8, GII.1, GII.3, and GII.4, and incubated at $30^{\circ} \mathrm{C}$ for $72 \mathrm{~h}$.

\section{Quantification of HuNoV VP1 by RT-PCR}

To detect HuNoV genome copies in the culture medium by quantitative RT-PCR, $300 \mu$ l of the supernatant was collected $72 \mathrm{~h}$ after infection. Total RNA was extracted from the supernatant and cells using $700 \mu \mathrm{l}$ of RNAiso Plus (Takara), according to the manufacturer's protocol. For cDNA synthesis, $10 \mu \mathrm{l}$ of RNA and $1 \mu \mathrm{l}$ of 6 -mer random primer (TaKaRa, Japan) were mixed and incubated at $65^{\circ} \mathrm{C}$ for $10 \mathrm{~min} ; 4 \mu \mathrm{l}$ of $5 \times$ Moloney murine leukemia virus (M-MLV) reverse transcriptase reaction buffer, $2 \mu \mathrm{l}$ of $5 \times$ dithiothreitol, $2 \mu \mathrm{l}$ of dNTP, $0.5 \mu \mathrm{l}$ of RNase inhibitor (Takara, Japan), and $1 \mu \mathrm{l}$ of M-MLV were then added, followed by incubation at $37^{\circ} \mathrm{C}$ for $1 \mathrm{~h}$ and $95^{\circ} \mathrm{C}$ for $5 \mathrm{~min}$ using a PCR Thermal Cycler Dice Gradient system. The cDNA was prepared using the HuNoV VP1 gene primer pair JJV2F (5'-CAA GAG TCA ATG TTT AGG TGG ATG AG-3') and COG2R (5'-TCG ACG CCA TCT TCA TTC AC-3') and probe primer RING2P (5'-FAM-TGG GAG GGC GAT CGC AAT CT-Black Hole Quencher) [23]. Quantitative analysis of the number of viral particles was carried out with Thermal Cycler Dice Real Time System III, and the titer was calculated by substituting the cycle threshold value from the qRT-PCR result as the $\mathrm{x}$ value in the equation $y=-3.498 x+42.305 ; R^{2}=0.9974$ was calculated from the HuNoV standard curve. The fold change of HuNoV copy number was calculated relative to the initial inoculum of the virus. The viral genome in the initial inoculum was detected after $1 \mathrm{~h}$ incubation and washing with PBS. 


\section{Transmission Electron Microscopy}

Norovirus-infected cells were detached from the plates using a cell scraper, then collected by centrifugation, and the cell pellets were fixed in 2.5\% glutaraldehyde (Electron Microscopy Sciences, USA) in 0.1 M phosphate buffer $\left(\mathrm{pH} 7.2\right.$ ) for $3 \mathrm{~h}$ at $4^{\circ} \mathrm{C}$. The pellet was then washed in several changes of $0.1 \mathrm{M}$ phosphate buffer to remove excess glutaraldehyde. Fixed samples were post-fixed in $1 \%$ osmium tetroxide (Electron Microscopy Sciences) in $0.1 \mathrm{M}$ phosphate buffer for $1-2 \mathrm{~h}$ in the dark at $4^{\circ} \mathrm{C}$. After osmium fixation, the pellets were washed 2-3 times with $0.1 \mathrm{M}$ phosphate buffer and dehydrated through a graded series of ethanol $(50 \%, 70 \%, 75 \%, 90 \%, 95 \%$, and 100\%). Dehydrated samples were exposed to two changes of propylene oxide, and then immersed in 2:1 (1 h), 1:1 (overnight), and 1:2 (1 h) mixtures of propylene oxide and Epon 812 (Electron Microscopy Sciences) embedding medium, respectively. The pellets were transferred to $100 \%$ epoxy resin and incubated overnight. Infiltrated samples were embedded in fresh pure epoxy resin and polymerized for $24-48 \mathrm{~h}$ at $70^{\circ} \mathrm{C}$. Using a Leica EM UC6 Ultramicrotome (Leica Microsystems $\mathrm{GmbH}$ ), polymerized blocks were cut into thin slices and mounted on 200mesh carbon-coated grids. The grids were post-stained with $2 \%$ uranyl acetate and $1 \%$ lead citrate at room temperature for 15 and 5 min, respectively. Zeiss LEO912AB $120 \mathrm{kV}$ TEM (Carl Zeiss) and FEI Tecnai G2 Spirit Twin $120 \mathrm{kV}$ TEM (FEI Company) were used for transmission electron microscopy analysis [24].

Relative Gene Expression at the Transcriptional Level in Host Cells in Response to HuNoV Replication

Quantitative RT-PCR was also used to measure the gene expression levels in response to HuNoV replication in the MDCK cells. RNA was extracted using $200 \mu \mathrm{l}$ of RNAiso Plus (TaKaRa) added to the cells at the infection endpoint, according to the manufacturer's manual. For cDNA synthesis, $10 \mu \mathrm{l}$ of RNA and $1 \mu \mathrm{l}$ of 6-mer random primer $(\mathrm{TaKaRa})$ were mixed and reacted at $65^{\circ} \mathrm{C}$ for $10 \mathrm{~min}$. Then, the cDNA synthesis kit $(4 \mu \mathrm{l}$ of $5 \times \mathrm{MMLV}$ RTase reaction buffer $+2 \mu \mathrm{l}$ of $5 \times \mathrm{DTT}+2 \mu \mathrm{l}$ of dNTP $+0.5 \mu \mathrm{l}$ of RNase inhibitor $+1 \mu \mathrm{l}$ of MMLV, TaKaRa) was added, and left to react at $37^{\circ} \mathrm{C}$ for $1 \mathrm{~h}$ and then at $95^{\circ} \mathrm{C}$ for $5 \mathrm{~min}$. The cDNA synthesis was performed using the PCR Thermal Cycler Dice Gradient (TaKaRa). The levels of replication-related genes in the prepared cDNA were quantified with Thermal Cycler Dice ${ }^{\otimes}$ Real-Time System III (TaKaRa). The primer sequences are given in Table S1.

\section{Statistical Analysis}

All experiments were performed in triplicate. Statistical data analysis was performed using IBM SPSS v. 23 software (IBM Corp., USA). Significant differences between groups were determined by one-way analysis of variance followed by Duncan's post-hoc test. Comparisons between two groups were performed with Student's $t$-test. A value of $p<0.05$ was considered statistically significant.

\section{Results}

\section{Optimal Cell Culture Conditions for HuNoV Replication}

To investigate the optimal temperature for viral replication in MDCK cells, HuNoV (GII.4 genotype)-infected MDCK cells (hereafter denoted as 'infected cells') were seeded at a density of $6.25 \times 10^{4} \mathrm{cells} / \mathrm{ml}$ and incubated in a 48 -well plate at $27^{\circ} \mathrm{C}, 30^{\circ} \mathrm{C}, 34^{\circ} \mathrm{C}$, and $37^{\circ} \mathrm{C}$ for $72 \mathrm{~h}$ (Fig. $1 \mathrm{~A}$ ). HuNoV replication was determined by measuring the RNA quantity of HuNoV VP1 gene in the infected cells using primers designed to amplify the VP1 [23]. The relative $\mathrm{HuNoV}$ copy numbers were 4.0-, 4.5-, 4.1-, and 1.9-fold higher than that of the initial inoculum at incubation temperatures of $27^{\circ} \mathrm{C}, 30^{\circ} \mathrm{C}, 34^{\circ} \mathrm{C}$, and $37^{\circ} \mathrm{C}$, respectively (Fig. $1 \mathrm{~A}$ ). The highest virus replication was observed at $30^{\circ} \mathrm{C}$, and the lowest replication was at $37^{\circ} \mathrm{C}$. Previous studies have typically used $37^{\circ} \mathrm{C}$ as the incubation temperature for in vitro virus culture and were therefore possibly not seeing replication [4]. To identify the optimal inoculum concentration for virus replication, the increase in the HuNoV genome copy number was measured at various concentrations of the virus inoculum $\left(5.6-2.28 \times 10^{2} \mathrm{HuNoV}\right.$ genome copies) in a 48-well plate. The HuNoV genome copy number was increased with increasing virus concentration, except for at 5.6 $\mathrm{HuNoV}$ genome copies (Fig. 1B). The highest fold-increase in the genome copy number was a 12.6-fold increase of inoculum concentration of $2.28 \times 10^{2} \mathrm{HuNoV}$ genome copies, followed by 5.7-, 5.6-, 3.0-fold increase of inoculum concentration of $\left.1.14 \times 10^{2}\right), 2.8 \times 10^{1}$ and $5.6 \times 10^{1} \mathrm{HuNoV}$ genome copies, respectively (Fig. 1B). To confirm the scalability of virus production and passaging of $\mathrm{HuNoV}$, the infected cells were incubated in different culture dishes, and the HuNoV copy number was measured. The infected cells were used as inoculum source for a series of three passages, meaning that the infected cells from the previous passage were used as an inoculum source for the following passage. Fig. $1 \mathrm{C}$ shows that the HuNoV genome copy number was increased by 6.3-, 30.6-, and 8.4-fold relative to that of the corresponding initial inoculum $\left(1.91 \times 10^{2}, 1.21 \times 10^{3}\right.$, and $1.85 \times 10^{4} \mathrm{HuNoV}$ genome copies) of the three consecutive passages, respectively. These results indicated that the passaging of HuNoV and scaling up of the virus production is possible in our culture system. Additionally, to identify the adaptability of the culture system, the replication of different HuNoV genotypes including GI.8, GII.1, GII.3, and GII.4 $\left(2.28 \times 10^{2}\right.$ $\mathrm{HuNoV}$ genome copies) were observed at $30^{\circ} \mathrm{C}$ for $72 \mathrm{~h}$ (Fig. 1D). Increases of 173-, 67-, 29-, and 13-fold in the virus copy number of GI.8, GII.1, GII.3, and GII.4, respectively, were observed relative to the initial inoculum level, demonstrating the high adaptability of the culture system for different genotypes. Although the replication of GII.4 was comparatively lower than that of the other genotypes, this genotype was selected for further experiments because it is the most common cause of global outbreaks [25].

\section{Expression of Genes Related to HuNoV Replication at Low Temperature}

To determine the mechanism for $\mathrm{HuNoV}$ replication at low temperature, the expression of different genes involved in viral replication at $30^{\circ} \mathrm{C}$ and $37^{\circ} \mathrm{C}$ were analyzed and compared to the level of respective genes in a 
A

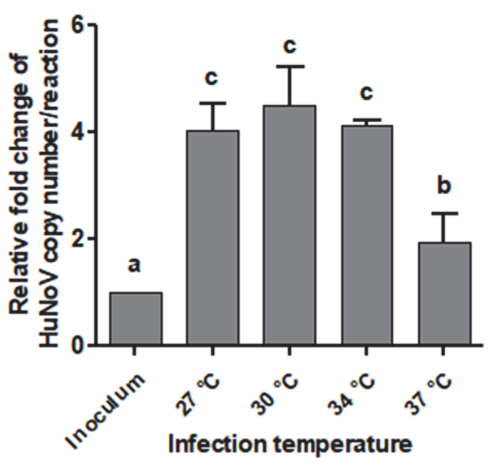

C

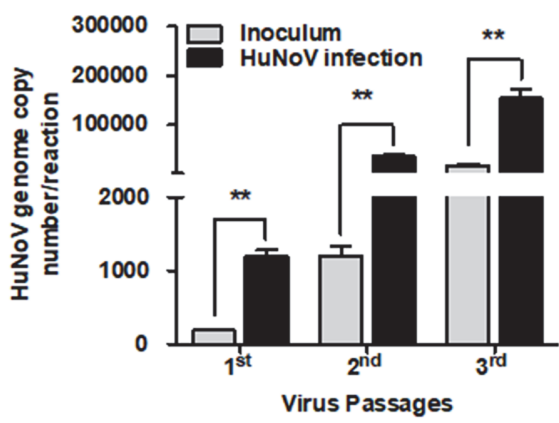

B

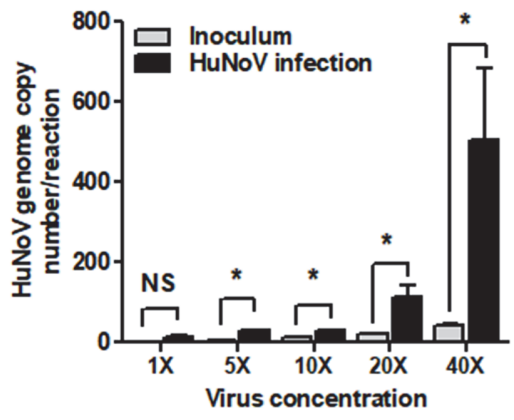

D

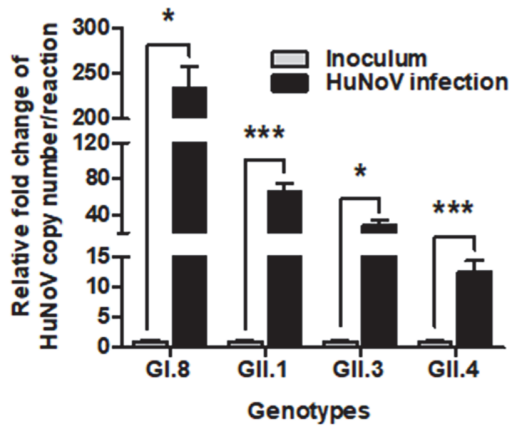

Fig. 1. Replication of human norovirus (HuNoV) in cell lines. (A) HuNoV (GII.4 genotype) replication in MDCK cells at different temperatures for $72 \mathrm{~h}$. (B) Evaluation of HuNoV replication efficiency in MDCK cells by the variation of HuNoV concentration (1X, 5.6; 5X, $2.8 \times 10^{1} ; 10 \mathrm{X}, 5.6 \times 10^{1} ; 20 \mathrm{X} 1.14 \times 10^{2}$; and 40X, $2.28 \times 10^{2} \mathrm{HuNoV}$ genome copies). (C) Evaluation of the passaging of HuNoV in MDCK cells on three consecutive passages. (D) Replication of different HuNoV genotypes $\left(2.28 \times 10^{2} \mathrm{HuNoV}\right.$ genome copies $)$ in MDCK cells at $30^{\circ} \mathrm{C}$ for $72 \mathrm{~h}$. Inoculum, virus inoculated MDCK cells after 1 $\mathrm{h}$ incubation and washing with PBS. Each bar represents the average of triplicate samples. Letters or asterisks indicate statistical differences among or between groups determined using ANOVA followed by Duncan’s $(p<0.05)$ or Student's $t$-test $\left({ }^{*} p<0.05\right.$, ${ }^{* *} p<0.01$ and $\left.{ }^{* * *} p<00.1\right)$, respectively.

mock-infected control that was prepared with thermally inactivated $\left(80^{\circ} \mathrm{C}\right.$ for $\left.30 \mathrm{~min}\right) \mathrm{HuNoV}$ obtained from fecal sample. The expression level of autophagy-related gene $A T G 5$ was decreased by 1.9 -fold at $30^{\circ} \mathrm{C}$; however, the level was increased by 1.6 -fold at $37^{\circ} \mathrm{C}$ in infected cells compared to the mock (Figs. 2A and 2B). A similar trend was observed for $A T G 7\left(2.84\right.$-fold decreased at $30^{\circ} \mathrm{C}$ and 1.5 -fold increased at $37^{\circ} \mathrm{C}$ ) (Figs. $2 \mathrm{~A}$ and $2 \mathrm{~B}$ ). Our results indicated that at $37^{\circ} \mathrm{C}, A T G 5$ and $A T G 7$ were induced and activated autophagy, resulting in virus degradation; thus, virus replication was reduced [26]. In contrast, at $30^{\circ} \mathrm{C}, A T G 5$ and $A T G 7$ expression levels were reduced, thereby preventing the decrease in autophagy in the antiviral response and thus supporting virus replication at low temperature [27]. Moreover, the expression of interferon (IFN)A, IFNB, IFN-stimulated gene (ISG)15, and nuclear factor-kappa $\mathrm{B}(\mathrm{NF}-\mathrm{\kappa B})$ was upregulated by $2.0-, 2.3-, 1.7$-, and 1.6- fold, respectively, at $37^{\circ} \mathrm{C}$ compared to that in their respective mock (Fig. $2 \mathrm{~A}$ ). Upregulation of the immune-related genes at $37^{\circ} \mathrm{C}$ could contribute to controlling the virus replication. However, either IFNB was downregulated or IFNA, ISG15 and NF- $\kappa B$ were not significantly different at $30^{\circ} \mathrm{C}$ compared to mock, thus allowing virus replication in infected cells at low temperature. The expression levels of genes associated with apoptosis, apoptosis regulator BAX (BAX), was decreased at $37^{\circ} \mathrm{C}$ and exceptionally increased at $30^{\circ} \mathrm{C}$ compared to mock. Even though other apoptosis-related genes, including cytochrome c (CYCS) and caspase (CASP-3) were significantly increased at both temperatures compared to mock, the pattern of the expression level was higher at $30^{\circ} \mathrm{C}$ compared to that at $37^{\circ} \mathrm{C}$ (Figs. $2 \mathrm{~A}$ and 2B). Since FOXO1 regulates several immune and autophagy related genes $[28,29]$ and inhibits virus replication [30], the expression of FOXO1 was analyzed in the infected cells. The result showed that the expression level of FOXO1 was decreased by 2.1 -fold at $30^{\circ} \mathrm{C}$ in contrast, and was increased by 1.6 -fold at $37^{\circ} \mathrm{C}$ in infected cells compared to mock (Figs. 2A and 2B).

Overall, these results suggest that at $37^{\circ} \mathrm{C}$, autophagy- and immune-related genes were upregulated in infected cells to promote the antiviral response to HuNoV infection; however, these genes were either inhibited or unchanged at $30^{\circ} \mathrm{C}$, thereby permitting viral replication.

Inhibition of FOXO1 Expression for HuNoV Replication

Next, the effect of FOXO1 inhibition on HuNoV replication was investigated by treating the infected cells with a FOXO1 inhibitor (AS1842856) [26] at $30^{\circ} \mathrm{C}$ and $37^{\circ} \mathrm{C}$. The HuNoV copy number was markedly increased by 7.5- 
A

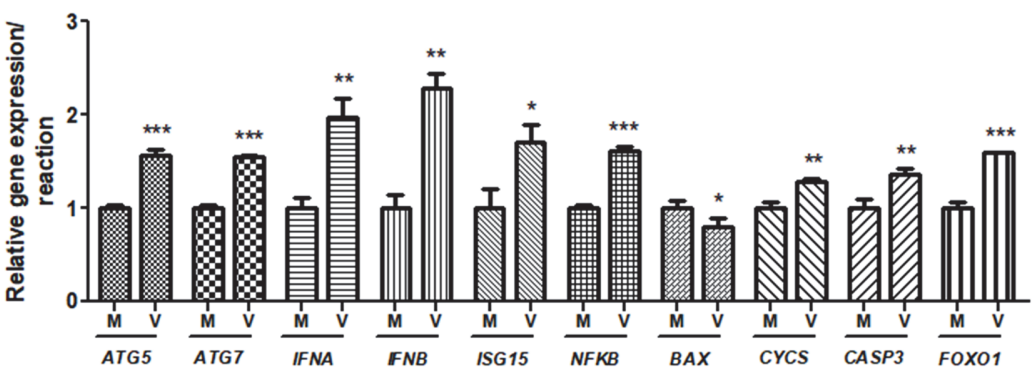

B

$30^{\circ} \mathrm{C}$

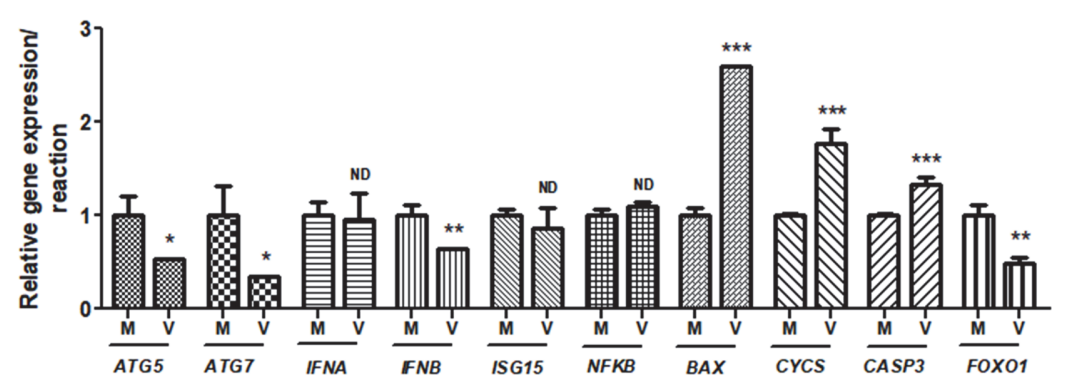

Fig. 2. Expression of genes in human norovirus (HuNoV)-infected MDCK cells at (A) $37^{\circ} \mathrm{C}$ and (B) $30^{\circ} \mathrm{C}$. Relative expression of ATG5, ATG7, IFNA, IFNB, ISG15, NFKB, BAX, CYCS, CASP3, and FOXO1 in the cells. MDCK cells were cultured for $24 \mathrm{~h}$, and infected with $1.92 \times 10^{2} \mathrm{HuNoV}$ genome copies at $37^{\circ} \mathrm{C}$ and $30^{\circ} \mathrm{C}$ for $24 \mathrm{~h}$. The gene expression was assessed by qRT-PCR and expressed relative to the expression in mock infected control. Asterisks above bars indicate the significant difference $\left({ }^{*} p<0.05,{ }^{* *} p<0.01,{ }^{* *} p<0.001\right)$ when compared to the corresponding gene expression in mock infected cells determined using $t$-test.
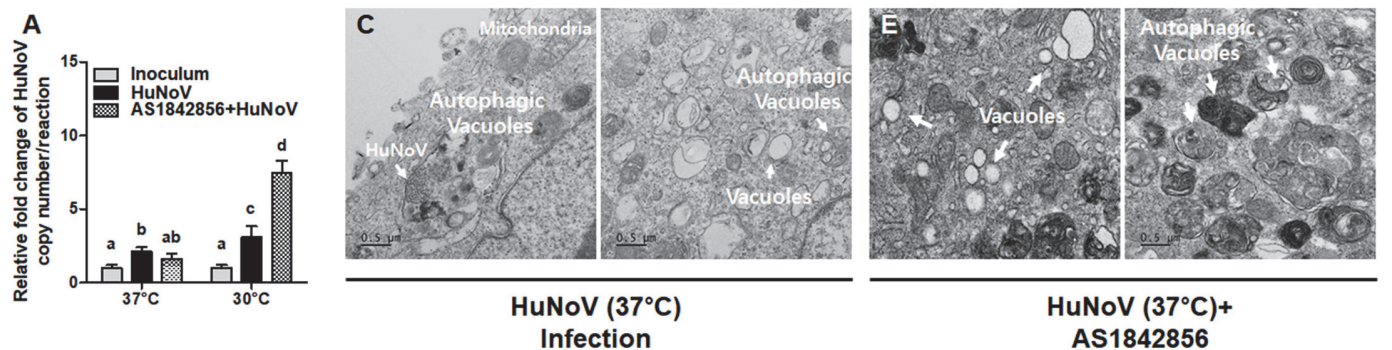

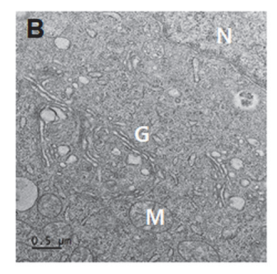

Control
HuNoV $\left(37^{\circ} \mathrm{C}\right)$

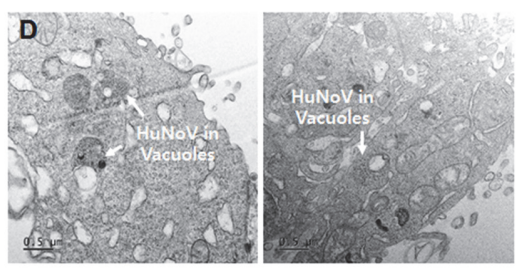

HuNoV $\left(30^{\circ} \mathrm{C}\right)$

Infection

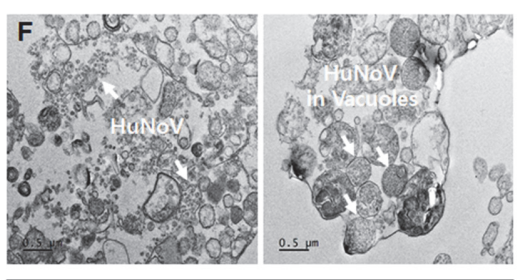

HuNoV $\left(30^{\circ} \mathrm{C}\right)+$

AS1842856

Fig. 3. Effect of FOXO1 inhibitor (AS1842856) in human norovirus (HuNoV) infection. (A) Change in relative fold of $\mathrm{HuNoV}$ copy number affected by FOXO1 inhibitor (AS1842856, $20 \mu \mathrm{M}$ ) at $37^{\circ} \mathrm{C}$ and $30^{\circ} \mathrm{C}$ in MDCK cells. Statistical difference was assessed using one-way ANOVA followed by Duncan's test $(p<0.05)$. (B-F) Transmission electron micrographs of uninfected control and HuNoV1.92 $\times 10^{2} \mathrm{HuNoV}$ genome copies) infected MDCK cells treated with FOXO1 inhibitor (AS1842856, $20 \mu \mathrm{M}$ ) at $37^{\circ} \mathrm{C}$ and $30^{\circ} \mathrm{C}$ for $72 \mathrm{~h}$. (B) Control group showing the presence of normal organelles such as Golgi bodies $(\mathrm{G})$, mitochondria $(\mathrm{M})$, and nuclei $(\mathrm{N})$. (C) Experimental group HuNoV-infected cells at $37^{\circ} \mathrm{C}$, with the presence of HuNoV surrounded by autophagic vacuoles. (D) Experimental group HuNoV-infected cells at $30^{\circ} \mathrm{C}$, with accumulation of $\mathrm{HuNoV}$ in vacuoles and cytoplasm. (E) Experimental group FOXO1 inhibitor-treated and HuNoV-infected cells at $37^{\circ} \mathrm{C}$. (F) Experimental group $\mathrm{FOXO} 1$ inhibitor-treated and $\mathrm{HuNoV}$-infected cells at $30^{\circ} \mathrm{C}$. Inoculum, virus inoculated MDCK cells after $1 \mathrm{~h}$ incubation and washing with PBS. 
fold following treatment with the inhibitor relative to that of the initial inoculum at $30^{\circ} \mathrm{C}$; however, replication was not significantly different at $37^{\circ} \mathrm{C}$ (Fig. $3 \mathrm{~A}$ ). The results indicate that FOXO1 inhibition only induced HuNoV replication at $30^{\circ} \mathrm{C}$.

To investigate the effect of FOXO1 inhibition on the cellular morphology of infected cells, ultrastructural analysis of FOXO1 inhibitor (AS1842856)-treated HuNoV-infected and uninfected cells was performed by transmission electron microscopy. Uninfected cells exhibited well-preserved cellular morphology with evenly distributed cell constituents, such as an intact nucleus (N), Golgi apparatus (G), and mitochondria (M) (Fig. 3B). The infected cells at $37^{\circ} \mathrm{C}$ displayed an increase in distinct membrane-bound autophagic vacuoles containing intracellular digested organelles [31]. Similar types of autophagic vacuole were observed in poliovirus and rhinovirus [32]. Such autophagic vacuoles were visualized in both FOXO1 inhibitor treated- and untreated$\mathrm{HuNoV}$ infected cells at $37^{\circ} \mathrm{C}$ (Figs. 3C and 3E). However, the destruction of cellular compartments and cytoplasmic clearing were distinctly observed in FOXO1 inhibitor treated-HuNoV infected cells at $30^{\circ} \mathrm{C}$ (Figs. 3D and 3F). Interestingly, in $\mathrm{FOXO1}$ inhibitor treated- $\mathrm{HuNoV}$ infected cells at $30^{\circ} \mathrm{C}, \mathrm{HuNoV}$, with a size of approximately $40 \mathrm{~nm}$, was more abundantly and clearly detected and was located either individually or in groups (Fig. 3F). Overall, the results suggested that the inhibition of FOXO1 may induce HuNoV replication by reducing the formation of autophagic vacuoles in the infected cells at low temperature. In addition, HuNoV infection affected cellular destruction, leading to distinctive ultrastructural features of apoptosis, whereas cell damage appeared to be more severe in cells infected at $30^{\circ} \mathrm{C}$ than in those infected at $37^{\circ} \mathrm{C}$ (Figs $3 \mathrm{D}$ and $3 \mathrm{E}$ ).

\section{Discussion}

In this study, a temperature-optimized cell culture model was developed and used to successfully replicate HuNoV using MDCK cells. A mechanism for replication in the model was also proposed. The successful replication of $\mathrm{HuNoV}$ in $\mathrm{B}$ cells and HIE in vitro were reported previously, with the cells requiring the additional cofactor HBGA and bile salt, respectively. However, Karst et al. reported that HBGA expression alone is not sufficient to enable virus replication in cell culture [2]; other several factors may affect virus replication. Moreover, genotypes GII.1 and GII.4 cannot bind to HBGA, but other numerous non-HBGA ligands have the potential to bind the genotypes $[33,34]$. The role of cell receptors in $\mathrm{HuNoV}$ replication remains controversial. For example, the presence of receptors such as sialoglycan does not support replication of HuNoV in the cells [19, 35]. Therefore, several factors, such as virus genotype and cell culture condition, may be responsible for virus replication in vitro.

All HuNoV genotypes did not replicate equally in the same culture model. In our model, the highest replication was observed for GI.8 and the lowest for GII.4. However, the model successfully replicated all tested genotypes, GI.8, GII.1, GII.3, and GII.4, indicating broad adaptability of the model (Fig. 1D). Similarly, Ettayebi et al. demonstrated successful replication of different genotypes in the HIE model in the presence of bile salt. However, a jejunal HIE model could only replicate GII genotypes [35]. The increase in virus copy number seems to be lower in our MDCK cell model than that in HIEs $[8,35]$, which could be due to lower concentration of virus inoculum used for the study. Increasing virus concentration $\left(2.28 \times 10^{2} \mathrm{HuNoV}\right.$ genome copies $)$ in inoculum increased by 12.6-fold the virus copy number in our model, indicating that the HuNoV replication also depends on viral concentration of inoculum. Moreover, modifying the cell culture conditions by lowering the temperature significantly increased HuNoV replication (Fig. 1A). Similarly, rhinovirus, a common cold virus, showed higher replication at a lower temperature $\left(33^{\circ} \mathrm{C}\right)$ than at $37^{\circ} \mathrm{C}$ because of reduced antiviral immune responses [20]. Chikungunya virus also showed higher replication at $22^{\circ} \mathrm{C}$ than at $30^{\circ} \mathrm{C}$ because INF expression was reduced [19]. Thus, replication at low temperature may be explained by variations in gene expression in the cell culture affected by temperature.

All tested autophagy-related genes, including ATG5 and ATG7, showed significantly increased expression levels in infected cells at $37^{\circ} \mathrm{C}$, suggesting that the expression of these genes suppressed virus replication. The genes protect cells from viral infection and support the maintenance of cellular homeostasis [36](Nardacci, Amendola, Ciccosanti, Corazzari, Esposito, Vlassi, et al., 2014). However, the role of autophagy was inconsistent in viral replication; viruses can manipulate autophagy signaling in either a suppressive or supportive manner [37]. Consistent with our results, previous studies reported that autophagy suppressed HIV-1, Sindbis, Epstein-Barr, and herpes simplex virus replication by trapping viral components or promoting the immune response [36, 3841]. In contrast, autophagy supported the replication of other viruses, such as hepatitis C, dengue, varicella-zoster, and influenza A viruses, as these viruses trigger autophagosome formation to facilitate their own replication [4245]. At $30^{\circ} \mathrm{C}$, decreased ATGs in HuNoV-infected cells indicated that inhibition of autophagy activates virus replication in the cells, possibly via inhibition of the autophagy-mediated antiviral immune system [37]. Hwang et al. also explained the role of the ATG complex in the IFN-mediated antiviral immune response against murine NoV for virus inhibition [46].

In the present study, upregulation of immune-related genes, including IFNA, IFNB, ISG15, and NF- $\mathrm{B}$, in infected cells at $37^{\circ} \mathrm{C}$, reflected activation of their antiviral role against HuNoV, thus suppressing virus replication. A previous study also demonstrated that IFN expression suppressed the replication of different viruses, including murine NoV [47]. On the other hand, unlike immune cell and in vivo studies, MDCK cells could not demonstrate IFN-induced antiviral activity against influenza virus, which could subsequently lower antiviral defense in the cells, and promote virus replication [48, 49]. Furthermore, ISG15 regulates the IFN-mediated antiviral immune response against different viruses, including murine NoV, influenza $\mathrm{A}$, hepatitis $\mathrm{C}$, and dengue viruses by covalently conjugating (ISGylation) to viral or cellular proteins to inhibit virus replication [50, 51]. On the other hand, either the suppression or unalteration of these immune-related genes at low culture temperature $\left(30^{\circ} \mathrm{C}\right)$ may 
increase virus replication in the cells [52]. Similarly, as described previously, rhinovirus chikungunya virus was reported to replicate at lower temperatures by suppressing the activity of IFNs and/or ISGs [19,20]. Inhibition of ISG15 significantly increased the replication of influenza A, Sindbis, and herpes viruses [53], and inhibition of the antiviral immune response of IFNs and ISGs is critical for virus replication [54]. Moreover, NF- $\kappa B$ regulates the expression levels of various immune responses against the virus [55]. Consistent with the results of our study, decreased homologous NF- $\mathrm{kB}$ activates the viral gene expression of HIV-1 and herpes simplex virus in cells by reducing host immune and inflammatory responses [56].

BAX was exceptionally induced at $30^{\circ} \mathrm{C}$ in the infected cells, resulting in apoptosis possibly through activation of $C A S P 3$ and $C Y C S$ at $30^{\circ} \mathrm{C}[57,58]$. Similarly, apoptosis in murine NoV-infected cells was reported to increase during virus replication via activation of CASP3 [59]. Moreover, functional apoptosis of cells caused by HuNoV infection was confirmed by TEM. In previous studies, HuNoV particles were observed in TEM images; however, their sizes were smaller than those observed in our study [8].

Finally, FOXO1 inhibition at low temperature induced HuNoV replication. Consistent with our result, FOXO1 inhibition also induced HIV and Kaposi's sarcoma-associated herpes virus replication in cells by inducing intracellular ROS levels $[30,60,61]$. However, the effect of culture temperature on FOXO1 expression was not observed previously. Notably, FOXO1 inhibition at low temperature may play a crucial role in virus replication because it modulates autophagy- and immunity-related genes and associated pathways [62].

In conclusion, this study demonstrated that $\mathrm{HuNoV}$ infection at $30^{\circ} \mathrm{C}$ can support virus replication in MDCK cells. The study revealed an unexpected link between temperature and the expression of FOXO1, which facilitated HuNoV replication in the cells. Thus, temperature-optimized MDCK cells can serve as a useful model for further studies to elucidate the pathogenic mechanisms of HuNoV infection.

\section{Acknowledgments}

This work was supported by a grant from the Korea Basic Science Institute's Biological Disaster Analysis Research Fund (Grant No. C39712) awarded to J.K.

\section{Conflict of Interest}

The authors have no financial conflicts of interest to declare.

\section{References}

1. Vinjé J. 2015. Advances in laboratory methods for detection and typing of norovirus. J Clin. Microbiol. 53: 373-381.

2. Karst SM. 2010. Pathogenesis of noroviruses, emerging RNA viruses. Viruses 2: 748-781.

3. Lopman BA, Steele D, Kirkwood CD, Parashar UD. 2016. The vast and varied global burden of norovirus: Prospects for prevention and control. PLoS Med. 13: e1001999.

4. Duizer E, Schwab KJ, Neill FH, Atmar RL, Koopmans MP, Estes MK. 2004. Laboratory efforts to cultivate noroviruses. J. Gen. Virol. 85: 79-87.

5. Lay MK, Atmar RL, Guix S, Bharadwaj U, He H, Neill FH, et al. 2010. Norwalk virus does not replicate in human macrophages or dendritic cells derived from the peripheral blood of susceptible humans. Virology 406: 1-11.

6. Papafragkou E, Hewitt J, Park GW, Greening G, Vinjé J. 2013. Challenges of culturing human norovirus in three-dimensional organoid intestinal cell culture models. PLoS One 8: e63485.

7. Takanashi S, Saif LJ, Hughes JH, Meulia T, Jung K, Scheuer KA, et al. 2014. Failure of propagation of human norovirus in intestinal epithelial cells with microvilli grown in three-dimensional cultures. Arch. Virol. 159: 257-266.

8. Ettayebi K, Crawford SE, Murakami K, Broughman JR, Karandikar U, Tenge VR, et al. 2016. Replication of human noroviruses in stem cell-derived human enteroids. Science 353: 1387-1393.

9. Jones MK, Grau KR, Costantini V, Kolawole AO, de Graaf M, Freiden P, et al. 2015. Human norovirus culture in B cells. Nat. Protoc. 10: 1939-1947.

10. Jones MK, Watanabe M, Zhu S, Graves CL, Keyes LR, Grau KR, et al. 2014. Enteric bacteria promote human and mouse norovirus infection of B cells. Science 346: 755-759.

11. Han L, Tan M, Xia M, Kitova EN, Jiang X, Klassen JS. 2014. Gangliosides are ligands for human noroviruses. J. Am. Chem. Soc. 136: 12631-12637.

12. Castro R, Fernandes P, Laske T, Sousa MFQ, Genzel Y, Scharfenberg K, et al. 2015. Production of canine adenovirus type 2 in serumfree suspension cultures of MDCK cells. Appl. Microbiol. Biotechnol. 99: 7059-7068.

13. Lin S-C, Kappes MA, Chen M-C, Lin C-C, Wang TT. 2017. Distinct susceptibility and applicability of MDCK derivatives for influenza virus research. PLoS One 12: e0172299.

14. Schultze B, Herrler G. 1995. Polarized entry of bovine coronavirus in epithelial cells, pp. 375-378. In P.J. Talbot and G. A. Levy (eds.), Corona-and Related Viruses, Springer, Boston, MA

15. Takada K, Kawakami C, Fan S, Chiba S, Zhong G, Gu C, et al. 2019. A humanized MDCK cell line for the efficient isolation and propagation of human influenza viruses. Nat. Microbiol. 4: 1268-1273.

16. Summa M, von Bonsdorff C-H, Maunula L. 2012. Pet dogs-A transmission route for human noroviruses? J. Clin. Virol. 53:244-247.

17. Boonarkart C, Suptawiwat O, Sakorn K, Puthavathana P, Auewarakul P. 2017. Exposure to cold impairs interferon-induced antiviral defense. Arch. Virol. 162: 2231-2237.

18. Dalton RM, Mullin AE, Amorim MJ, Medcalf E, Tiley LS, Digard P. 2006. Temperature sensitive influenza A virus genome replication results from low thermal stability of polymerase-cRNA complexes. Virol. J. 3: 58

19. Prow NA, Tang B, Gardner J, Le TT, Taylor A, Poo YS, et al. 2017. Lower temperatures reduce type I interferon activity and promote alphaviral arthritis. PLoS Pathog. 13: e1006788.

20. Foxman EF, Storer JA, Fitzgerald ME, Wasik BR, Hou L, Zhao H, et al. 2015. Temperature-dependent innate defense against the common cold virus limits viral replication at warm temperature in mouse airway cells. Proc. Natl. Acad. Sci. USA 112: 827-832.

21. Lei C-Q, Zhang Y, Xia T, Jiang L-Q, Zhong B, Shu H-B. 2013. FOXO1 negatively regulates cellular antiviral response by promoting degradation of IRF3. J. Biol. Chem. 288: 12596-12604.

22. Shlomai A, Shaul Y. 2009. The metabolic activator FOXO1 binds hepatitis B virus DNA and activates its transcription. Biochem. Biophys. Res. Commun. 381: 544-548. 
23. Yoo JE, Lee C, Park S, Ko G. 2017. Evaluation of various real-time reverse transcription quantitative PCR assays for norovirus detection. J. Microbiol. Biotechnol. 27: 816-824.

24. Straub TM, Hutchison JR, Bartholomew RA, Valdez CO, Valentine NB, Dohnalkova A, et al. 2013. Defining cell culture conditions to improve human norovirus infectivity assays. Water Sci. Technol. 67: 863-868.

25. Atmar RL, Ramani S, Estes MK. 2018. Human noroviruses: recent advances in a 50-year history. Curr. Opin. Infect. Dis. 31: $422-432$.

26. Shibutani ST, Saitoh T, Nowag H, Münz C, Yoshimori T. 2015. Autophagy and autophagy-related proteins in the immune system. Nat. Immunol. 16: 1014.

27. Yordy B, Tal MC, Hayashi K, Arojo O, Iwasaki A. 2013. Autophagy and selective deployment of Atg proteins in antiviral defense. Int. Immunol. 25: 1-10.

28. Dejean AS, Hedrick SM, Kerdiles YM. 2011. Highly specialized role of Forkhead box O transcription factors in the immune system. Antioxid. Redox Signal. 14: 663-674.

29. Sengupta A, Molkentin JD, Yutzey KE. 2009. FOXO transcription factors promote autophagy in cardiomyocytes. J. Biol. Chem. 284: 28319-28331.

30. Trinité B, Chan CN, Lee CS, Mahajan S, Luo Y, Muesing MA, et al. 2014. Suppression of FOXO1 activity and down-modulation of CD62L (L-Selectin) in HIV-1 infected resting CD4 T cells. PLoS One 9: e110719.

31. Martinet W, Timmermans J-P, De Meyer GR. 2014. Methods to assess autophagy in situ-transmission electron microscopy versus immunohistochemistry, pp. 89-114. In L. Galluzzi and G. Kroemer (eds.) Methods in Enzymology, Elsevier, Oxford, UK.

32. Jackson WT, Giddings TH, Jr., Taylor MP, Mulinyawe S, Rabinovitch M, Kopito RR, et al. 2005. Subversion of cellular autophagosomal machinery by RNA viruses. PLoS Biol. 3: e156.

33. Almand EA, Moore MD, Jaykus L-A. 2017. Norovirus binding to ligands beyond histo-blood group antigens. Front. Microbiol. 8: 2549 .

34. Lindesmith LC, Donaldson EF, LoBue AD, Cannon JL, Zheng D-P, Vinje J, et al. 2008. Mechanisms of GII.4 norovirus persistence in human populations. PLoS Med. 5: e31.

35. Costantini V, Morantz EK, Browne H, Ettayebi K, Zeng X-L, Atmar RL, et al. 2018. Human norovirus replication in human intestinal enteroids as model to evaluate virus inactivation. Emerg. Infect. Dis. 24: 1453-1464.

36. Nardacci R, Amendola A, Ciccosanti F, Corazzari M, Esposito V, Vlassi C, et al. 2014. Autophagy plays an important role in the containment of HIV-1 in nonprogressor-infected patients. Autophagy 10: 1167-1178.

37. Choi Y, Bowman JW, Jung JU. 2018. Autophagy during viral infection - a double-edged sword. Nat. Rev. Microbiol. 16: 341-354.

38. De Leo A, Colavita F, Ciccosanti F, Fimia GM, Lieberman PM, Mattia E. 2015. Inhibition of autophagy in EBV-positive Burkitt's lymphoma cells enhances EBV lytic genes expression and replication. Cell Death Dis. 6: e1876.

39. Orvedahl A, MacPherson S, Sumpter Jr R, Tallóczy Z, Zou Z, Levine B. 2010. Autophagy protects against Sindbis virus infection of the central nervous system. Cell Host Microbe. 7: 115-127.

40. Sagnier S, Daussy CF, Borel S, Robert-Hebmann V, Faure M, Blanchet FP, et al. 2015. Autophagy restricts HIV-1 infection by selectively degrading Tat in CD4+ T lymphocytes. J. Virol. 89: 615-625.

41. Yordy B, Iijima N, Huttner A, Leib D, Iwasaki A. 2012. A neuron-specific role for autophagy in antiviral defense against herpes simplex virus. Cell Host Microbe. 12: 334-345.

42. Buckingham EM, Jarosinski KW, Jackson W, Carpenter JE, Grose C. 2016. Exocytosis of varicella-zoster virus virions involves a convergence of endosomal and autophagy pathways. J. Virol. 90: 8673-8685.

43. Fang Y-T, Wan S-W, Lu Y-T, Yao J-H, Lin C-F, Hsu L-J, et al. 2014. Autophagy facilitates antibody-enhanced dengue virus infection in human pre-basophil/mast cells. PLoS One 9: e110655.

44. Wang L, Tian Y, Ou J-hJ. 2015. HCV induces the expression of rubicon and UVRAG to temporally regulate the maturation of autophagosomes and viral replication. PLoS Pathog. 11: e1004764.

45. Zhou Z, Jiang X, Liu D, Fan Z, Hu X, Yan J, et al. 2009. Autophagy is involved in influenza A virus replication. Autophagy 5: 321-328.

46. Hwang S, Maloney NS, Bruinsma MW, Goel G, Duan E, Zhang L, et al. 2012. Nondegradative role of Atg5-Atg12/Atg16L1 autophagy protein complex in antiviral activity of interferon gamma. Cell Host Microbe. 11: 397-409.

47. Samuel CE. 2001. Antiviral actions of interferons. Clin. Microbiol. Rev. 14: 778-809.

48. Frensing T, Seitz C, Heynisch B, Patzina C, Kochs G, Reichl U. 2011. Efficient influenza B virus propagation due to deficient interferon-induced antiviral activity in MDCK cells. Vaccine 29: 7125-7129.

49. Seitz C, Frensing T, Höper D, Kochs G, Reichl U. 2010. High yields of influenza A virus in Madin-Darby canine kidney cells are promoted by an insufficient interferon-induced antiviral state. J. Gen. Virol. 91: 1754-1763.

50. Perng Y-C, Lenschow DJ. 2018. ISG15 in antiviral immunity and beyond. Nat. Rev. Microbiol. 16: 423-439.

51. Rodriguez MR, Monte K, Thackray LB, Lenschow DJ. 2014. ISG15 functions as an interferon-mediated antiviral effector early in the murine norovirus life cycle. J. Virol. 88: 9277-9286.

52. Scheller J, Chalaris A, Schmidt-Arras D, Rose-John S. 2011. The pro-and anti-inflammatory properties of the cytokine interleukin-6. Biochim. Biophys. Acta 1813: 878-888.

53. Lenschow DJ, Lai C, Frias-Staheli N, Giannakopoulos NV, Lutz A, Wolff T, et al. 2007. IFN-stimulated gene 15 functions as a critical antiviral molecule against influenza, herpes, and Sindbis viruses. Proc. Natl. Acad. Sci. USA 104: 1371-1376.

54. Beachboard DC, Horner SM. 2016. Innate immune evasion strategies of DNA and RNA viruses. Curr. Opin. Microbiol. 32: $113-119$.

55. Rahman MM, McFadden G. 2011. Modulation of NF- $\kappa B$ signalling by microbial pathogens. Nat. Rev. Microbiol. 9: 291.

56. Zhao J, He S, Minassian A, Li J, Feng P. 2015. Recent advances on viral manipulation of NF-kB signaling pathway. Curr. Opin. Virol. 15: 103-111.

57. Bitzer M, Prinz F, Bauer M, Spiegel M, Neubert WJ, Gregor M, et al. 1999. Sendai virus infection induces apoptosis through activation of caspase-8 (FLICE) and caspase-3 (CPP32). J. Virol. 73: 702-708.

58. Ye X, Zhou X-J, Zhang H. 2018. Exploring the role of autophagy-related gene 5 (ATG5) yields important insights into autophagy in autoimmune/autoinflammatory diseases. Front. Immunol. 9: 2334.

59. Bok K, Prikhodko VG, Green KY, Sosnovtsev SV. 2009. Apoptosis in murine norovirus-infected RAW264.7 cells is associated with downregulation of survivin. J. Virol. 83: 3647-3656.

60. Gao R, Li T, Tan B, da Silva SR, Jung JU, Feng P, et al. 2019. FOXO1 suppresses Kaposi's sarcoma-associated herpesvirus lytic replication and controls viral latency. J. Virol. 93: e01681-18.

61. Roux A, Leroy H, De Muylder B, Bracq L, Oussous S, Dusanter-Fourt I, et al. 2019. FOXO1 transcription factor plays a key role in T cell-HIV-1 interaction. PLoS Pathog. 15: e1007669.

62. Xing Y-q, Li A, Yang Y, Li X-x, Zhang L-n, Guo H-c. 2018. The regulation of FOXO1 and its role in disease progression. Life Sci. 193: 124-131. 